\title{
Raquianestesia para Cirurgia Ortopédica de Urgência em Paciente Portadora de Doença de Von Recklinghausen. Relato de Caso *
}

\section{Spinal Block for Urgency Orthopedic Surgery in Von Recklinghausen's Disease Patient. Case Report}

\author{
Fabiano Timbó Barbosa, TSA ${ }^{1}$; Alexandre Vieira Figueiredo, TSA ${ }^{2}$; Rafael Martins da Cunha ${ }^{3}$;
} Marcos Antônio Costa de Albuquerque, TSA ${ }^{4}$

\section{RESUMO}

Barbosa FT, Figueiredo AV, Cunha RM, Albuquerque MAC - Raquianestesia para Cirurgia Ortopédica de Urgência em Paciente Portadora de Doença de Von Recklinghausen. Relato de Caso

JUSTIFICATIVA E OBJETIVOS: A doença de Von Recklinghausen é uma doença neurogenética causada por uma anomalia no cromossomo 17. O objetivo deste relato foi descrever a conduta anestésica em paciente com doença de Von Recklinghausen submetida à cirurgia ortopédica de urgência.

RELATO DO CASO: Paciente do sexo feminino, 28 anos, portadora da doença de Von Recklinghausen, submetida à cirurgia ortopédica em hospital de emergência sob raquianestesia. Não apresentou complicações no período intra-operatório, nem na sala de recuperação pós-anestésica. Teve alta hospitalar no $4^{\circ}$ dia de pós-operatório.

CONCLUSÕES: No caso relatado foi possível a realização da raquianestesia sem haver necessidade de manuseio da via aérea.

Unitermos: DOENÇAS: Von Recklinghausen; TÉCNICAS ANESTÉSICAS, Regional: subaracnóidea

\footnotetext{
* Recebido da (Received from) Unidade de Emergência Dr. Armando Lages, Maceió, $A L$

1. Especialista em Docência para o Ensino Superior conferido pelo Centro de Ensino Superior de Maceió, anestesiologista da Unidade de Emergência Dr. Armando Lages em Maceió; Intensivista da Clínica Santa Juliana em Maceió e da Santa Casa de Misericórdia de São Miguel dos Campos em Alagoas

2. Especialista em Terapia Antálgica, Membro da Câmara Técnica de Anestesiologia do CREMEB, Anestesiologista da Clínica São Marcos e do Hospital Ana Néri, Salvador, BA

3. Professor de farmacologia do Centro de Ensino Superior de Maceió, Professor Convidado de Farmacologia da Escola de Ciências Médicas de Alagoas, Anestesiologista do Hospital Unimed - Maceió, AL

4. Diretor Científico da SAESE, Membro do Comitê de Anestesia Venosa da SBA, Diretor Geral do Hospital Governador João Alves Filho, Anestesiologista da Universidade Federal de Sergipe, Anestesiologista do Hospital São Lucas e Diagnose
}

Apresentado (Submitted) em 03 de março de 2005

Aceito (Accepted) para publicação em 28 de junho de 2005

Endereço para correspondência (Correspondence to)

Dr. Fabiano Timbó Barbosa

Rua Comendador Palmeira, 113/202 Ed. Erich Fromm - Farol

57051-150 Maceió, AL

E-mail:fabianotimbo@yahoo.com.br

(c) Sociedade Brasileira de Anestesiologia, 2005

Revista Brasileira de Anestesiologia

\section{SUMMARY}

Barbosa FT, Figueiredo AV, Cunha RM, Albuquerque MAC Spinal Block for Urgency Orthopedic Surgery in Von Recklinghausen's Disease Patient. Case Report

BACKGROUND AND OBJECTIVES: Von Recklinghausen's disease is a neurogenetic disease due to chromosome $17 \mathrm{ab}$ normality. This report aimed at describing the anesthetic approach for Von Recklinghausen's disease patient submitted to urgency orthopedic surgery.

CASE REPORT: Female patient, 28 years old, with Von Recklinghausen's disease, submitted to emergency orthopedic surgery under spinal block. There have been no complications both in the intraoperative period and in the post-anesthetic care unit. Patient was discharged 4 days later.

CONCLUSIONS: Spinal block was possible in this case with no need for airway handling.

Key Words: ANESTHETIC TECHNIQUES, Regional: spinal block; DISEASES: Von Recklinghausen's

\section{INTRODUÇÃO}

neurofibromatose refere-se a pelo menos duas doenAças genéticas autossômicas dominantes com máculas café-com-leite na pele e um ou mais neurofibromas ${ }^{1}$. Classicamente é dividida em tipos I e II.

A neurofibromatose tipos I (NF1) também pode ser chamada de doença de Von Recklinghausen e é a forma mais comum ${ }^{1}$. Ela é freqüentemente associada a uma variedade de condições clínicas que necessitam tratamento cirúrgico, como ${ }^{1}$ : neurofibroma doloroso, escoliose grave, pseudo-artrose congênita, hidrocefalia, tumores intracranianos e medulares. Os neurofibromas podem sofrer degeneração maligna secundária e tornarem-se sarcomas ${ }^{2}$.

A neurofibromatose tipo II se deve a uma alteração no cromossomo 22 que geralmente está acompanhada de schwannoma vestibular bilateral ${ }^{2}$. As máculas café-com-leite e os neurofibromas periféricos ocorrem raramente e a deficiência auditiva geralmente se torna sintomática na terceira década de vida ${ }^{2}$.

O objetivo deste relato foi apresentar um caso de paciente portadora desta doença e a conduta anestésica adotada.

\section{RELATO DO CASO}

Paciente do sexo feminino, 28 anos, $57 \mathrm{~kg}$, com diagnóstico de doença de Von Recklinghausen, deu entrada em hospital 
de emergência para tratamento de fratura exposta de tíbia. $\mathrm{Na}$ avaliação pré-operatória, negou qualquer sinal ou sintoma que pudesse ser relacionado ao comprometimento do sistema nervoso central pela presença de neurofibromas. A avaliação sistemática não apurou anormalidades. Ao exame apresentava-se tranqüila, eupnéica, hidratada, mucosas coradas, pressão arterial de $120 \times 60 \mathrm{mmHg}$ e com freqüência cardíaca de $80 \mathrm{bpm}$. O restante do exame físico segmentar apresentava-se sem alterações e sem sinais de neoplasias. Durante a avaliação pré-operatória evidenciou-se disfonia cujo início foi relatado alguns anos antes do procedimento de urgência. Os exames complementares, constituídos por hemograma, glicemia, contagem de plaquetas e radiografia de tórax, mostraram-se sem alterações. A paciente negou passado de hipertensão arterial sistêmica.

$\mathrm{Na}$ chegada à sala de operação foi realizada monitorização com oxímetro de pulso, cardioscópio e pressão arterial não-invasiva. Foi feita a punção venosa com cateter $18 \mathrm{G}$ para hidratação com solução de Ringer com lactato.

O bloqueio subaracnóideo foi realizado com a paciente na posição sentada, com tração manual do membro fraturado. Foi realizada punção lombar mediana, entre a terceira e a quarta vértebra, com agulha Whitacre $27 \mathrm{G}$, onde foram administrados $3 \mathrm{~mL}$ de bupivacaína hiperbárica a $0,5 \%$. O procedimento anestésico transcorreu sem intercorrências. A paciente foi mantida em decúbito dorsal com administração de oxigênio através de cateter nasal com fluxo de $5 \mathrm{~L}$. $\mathrm{min}^{-1}$.

O bloqueio sensitivo foi testado seqüencialmente com aguIha e ao atingir o dermátomo $\mathrm{T}_{12}$ foi iniciada a cirurgia. A ocorrência de hipotensão arterial intra-operatória foi tratada com um total de $5 \mathrm{mg}$ de etilefrina venosa em bolus intermitente de $1 \mathrm{mg}$. Associada ao vasopressor; também foi realizado bolus de $250 \mathrm{~mL}$ de solução de Ringer com lactato. Aquantidade total de cristalóide durante todo o procedimento foi de $3000 \mathrm{~mL}$. A cirurgia teve duração de 150 minutos e a paciente, ao final, foi encaminhada à sala de recuperação pós-anestésica, onde permaneceu por 12 horas sem intercorrência. A alta hospitalar ocorreu no quarto dia de pós-operatório.

\section{DISCUSSÃO}

A doença de Von Recklinghausen é um distúrbio genético transmitido através de herança autossômica dominante com penetrância variável ${ }^{2}$. Origina-se a partir da proliferação das células de Schwann e dos fibroblastos ${ }^{3}$.

A doença é progressiva ${ }^{4}$, piora na puberdade ${ }^{5}$ e é mais freqüente no sexo masculino ${ }^{6}$. Nas mulheres, pode também piorar durante a gravidez ${ }^{4,5}$.

A NF1 apresenta uma incidência aproximada de um para cada 3000 nascimentos ${ }^{7-9}$, sendo um dos distúrbios neurogenéticos mais comuns ${ }^{8}$.

A patogênese molecular da doença pode ser explicada pela ausência da síntese de uma proteína chamada neurofibromina ${ }^{2,8,10}$ que é composta por 2818 aminoácidos ${ }^{8}$. A análise molecular da neurofibromina revelou similaridade entre parte dela e o domínio catalítico de uma proteína que funciona como reguladora negativa da Ras guanosina trifosfato GTPase ${ }^{8}$. Em muitas células a Ras GTP facilita a transformação oncogenética tanto in vivo como in vitro ${ }^{8}$. A perda da expressão genética da NF1 leva à ausência da neurofibromina, a aumento da atividade Ras GTP com conseqüente aumento da proliferação celular e da formação de tumores ${ }^{8}$. Uma mutação no cromossomo 17 é responsável pela NF1 ${ }^{2,10}$.

A doença pode ser clinicamente caracterizada por máculas café-com-leite ${ }^{5}$, neurofibromas cutâneo, neural ou vascular; tumores intracranianos e medulares; alterações esqueléticas, estenose pulmonar, baixa estatura, anormalidades endócrinas e dificuldade no aprendizado. Algumas doenças associadas também merecem citação, como o feocromocitoma $^{9,11,12}$, o carcinoma medular de tireóide ${ }^{7,11}$, o rim policísti$\mathrm{co}^{7}$, o aneurisma de aorta ${ }^{7}$ e a estenose de artéria renal ${ }^{9,13}$.

O diagnóstico pode ser feito pela presença de pelo menos seis máculas café-com-leite com mais de $1,5 \mathrm{~cm}$ de diâmetro. O aparecimento de neurofibromas cutâneos ou subcutâneos na infância confirmam o diagnóstico ${ }^{13}$.

A presença de neurofibroma faríngeo ${ }^{12}$, laríngeo ${ }^{12}$, em mediastino ${ }^{5}$ e a macroglossia ${ }^{10}$ podem levar à obstrução das vias aéreas que clinicamente se manifesta por dispnéia, disfagia ou disfonia ${ }^{12}$.

As alterações esqueléticas ocorrem em $50 \%$ dos casos e incluem ${ }^{11}$ escoliose, deformidade mandibular, pseudo-artrose congênita e anormalidades cervicais.

Aescoliose ocorre em $2 \%$ dos pacientes ${ }^{9}$, comprometendoa mecânica respiratória, as trocas gasosas e a circulação pulmonar ${ }^{14}$. O desenvolvimento anormal da caixa torácica tem efeito direto nas propriedades elásticas do sistema respiratório ${ }^{14}$. Ocorre alteração na relação entre ventilação e perfusão pulmonar com o desenvolvimento de hipoventilação generalizada ${ }^{14}$. Com o envelhecimento pode surgir hipertensão de artéria pulmonar, insuficiência respiratória e cor pulmonale ${ }^{14}$.

O comprometimento cervical se deve à infiltração tumoral ou à anormalidade nos ligamentos espinhais com possibilidade de luxação atlanto-occipital ${ }^{15}$.

A presença de neurofibroma plexiforme gigante na cabeça pode levar a ptose palpebral, gigantismo facial e problemas visuais ${ }^{15}$. Macroglossia também pode ocorrer ${ }^{10}$. As deformidades faciais exigem tratamento cirúrgico ${ }^{15}$.

O feocromocitoma ocorre em aproximadamente $1 \%{ }^{9,12,13}$ dos pacientes e é a principal causa de hipertensão arterial sistêmica (HAS) em adultos ${ }^{6}$. Sua ocorrência nas crianças é rara ${ }^{5,9}$ e nesse grupo de pacientes a HAS ocorre mais comumente por estenose de artéria renal ${ }^{13}$.

Alguns exames são recomendados previamente às cirurgias com a finalidade de prevenir complicações e auxiliar na escoIha da melhor técnica anestésica de forma individualizada.

Atomografia computadorizada, a ressonância magnética ea laringoscopia indireta estão indicadas para avaliar o comprometimento das vias aéreas ${ }^{12}$. A traqueostomia pré-operatória deve ser considerada para garantir a segurança na realização da anestesia geral.

Em pacientes com escoliose e doença pulmonar é necessário fazer radiografia de tórax, gasometria e espirometria ${ }^{12}$. 
Em todos os pacientes é recomendável a determinação dos níveis urinários de catecolaminas devido a sua associação com o feocromocitoma ${ }^{12}$. Os valores normais para urina de 24 horas estão abaixo de $0,1 \mathrm{mg}$ de adrenalina livre e noradrenalina, 1,3 mg de metanefrina total, $10 \mathrm{mg}$ de ácido vanilmandélico e $15 \mathrm{mg}$ de ácido homovanílico. Coma, desidratação ou estados de estresse excessivo elevam a excreção desses componentes ${ }^{16}$.

A avaliação da função hipofisária é recomendável em pacientes com baixa estatura ou que refiram disfunção sexual.

A anestesia geral pode ser executada com sucesso em pacientes com a doença de Von Recklinghausen quando se pesquisa adequadamente a possibilidade de obstrução das vias aéreas e quando se valoriza a sensibilidade aos bloqueadores neuromusculares.

A dificuldade de intubação ocorre devido à obstrução no trajeto das vias aéreas pela presença de neurofibroma, principalmente na laringe e faringe. Pacientes com passado de intubação sem complicações não estão isentos dos riscos, já que a doença é progressiva ${ }^{7}$. Há relato de impossibilidade de ventilação sob máscara com realização de traqueostomia após indução anestésica ${ }^{10}$.

Os pacientes com NF1 apresentam um aumento da sensibilidade aos bloqueadores neuromusculares não-despolarizantes $^{4,5,8-10,12,13}$. Um defeito no receptor pré-sináptico e ou uma alteração na resposta de receptor pós-sináptico podem explicar essa alteração de resposta ${ }^{4}$. A monitorização da função neuromuscular é recomendável, quando for planejada anestesia geral com essa classe de fármacos ${ }^{9,10,12}$.

A literatura é controversa em relação ao uso da succinilcolina. Alguns autores referem sensibilidade diminuída ${ }^{4}$, outros normal $^{6,11}$ e outros, aumentada ${ }^{5,7,9,10,13}$.

Tem sido relatado que o bloqueio no neuro-eixo pode ser executado com sucesso ${ }^{4,5,7,12,13,17}$. No caso em questão, devido à situação de urgência, não foi possível realizar exames mais completos no pré-operatório e a escolha pela raquianestesia fundamentou-se em poupar a paciente dos riscos da intubação orotraqueal. Dificuldade técnica pode ocorrer devido ao desvio acentuado da coluna ${ }^{13}$ ou a presença de neurofibroma assintomático no trajeto da agulha ${ }^{7,13}$, inexistentes na referida paciente.

No caso relatado foi possível a realização da raquianestesia sem haver necessidade de manuseio da via aérea.

\section{Spinal Block for Urgency Orthopedic Surgery in Von Recklinghausen's Disease Patient. Case Report}

Fabiano Timbó Barbosa, TSA, M.D.; Alexandre Vieira Figueiredo, TSA, M.D.; Rafael Martins da Cunha, M.D.; Marcos Antônio Costa de Albuquerque, TSA, M.D.

\section{INTRODUCTION}

Neurofibromatosis is related to at least two dominant autosomal genetic diseases with café au lait spots on the skin and one or more neurofibromas ${ }^{1}$. It is classically divided in types I and II.

Type I neurofibromatosis (NF1) is also called Von Recklinghausen disease and is the most common presentation ${ }^{1}$. It is often associated to different clinical conditions needing surgical treatment, such as ${ }^{1}$ : painful neurofibroma, severe scoliosis, congenital pseudo-arthritis, hydrocephalus, intracranial and medullary tumors. Neurofibromas may suffer secondary malignant degeneration and become sarcomas $^{2}$.

Type II neurofibromatosis is caused by a change in chromosome 22 and is often followed by bilateral vestibular shwannoma ${ }^{2}$. Café au lait spots and peripheral neurofibromas are uncommon and auditory impairment is in general symptomatic in the third decade of life ${ }^{2}$.

This report aimed at presenting a patient with this disease and the anesthetic approach adopted.

\section{CASE REPORT}

Female patient, 28 years old, $57 \mathrm{~kg}$, with Von Recklinghausen disease, referred to an emergency hospital with exposed tibial fracture. During preoperative evaluation she denied any sign or symptom that could be related to central nervous system impairment by the presence of neurofibromas. Evaluation was normal and patient presented relaxed, eupneic, hydrated, normal color of mucosa, blood pressure of $120 \times 60$ $\mathrm{mmHg}$ and heart rate of $80 \mathrm{bpm}$. Remaining physical evaluation was normal with no signs of neoplasias.

Dysphonia was evidenced during preoperative evaluation, which appeared some years before the surgical procedure. Additional tests - blood count, glycemia, platelet count and chest X-Rays - were normal. Patient denied history of systemic hypertension.

Monitoring in the operating room consisted of pulse oximetry, cardioscope and noninvasive blood pressure. Intravenous puncture was achieved with $18 \mathrm{G}$ catheter and lactated Ringer's infusion was initiated.

Spinal block was performance with patient in the sitting position and manual traction of the fractured leg. Median lumbar puncture was performed between the third and fourth vertebrae, with $27 \mathrm{G}$ Whitacre needle and $03 \mathrm{~mL}$ of $0.5 \%$ hyperbaric bupivacaine were injected. Anesthesia went on without 
intercurrences. Patient was maintained in the supine position with oxygen through nasal catheter with a flow $5 \mathrm{~L}$. $\mathrm{min}^{-1}$ of. Sensory block was sequentially tested with needle and when dermatome $\mathrm{T}_{12}$ was reached, surgery was started. Intraoperative hypotension was treated with a total of $5 \mathrm{mg}$ intravenous ethylphenylephrine in $1 \mathrm{mg}$ intermittent bolus. Bolus of $250 \mathrm{~mL}$ lactated Ringer's were also associated to the vasopressor. Total crystalloids during procedure was 3000 $\mathrm{mL}$. Surgery lasted 150 minutes and patient was referred to post-anesthetic recovery unit where she remained for 12 hours without intercurrences, being discharged 4 days later.

\section{DISCUSSION}

Von Recklinghausen's disease is a genetic disorder transmitted by dominant autosomal heritage with variable penetration $^{2}$. It originates from the proliferation of Schwann cells and fibroblasts ${ }^{3}$.

Disease is progressive ${ }^{4}$, worsens with pregnancy ${ }^{4,5}$ and during puberty ${ }^{5}$, and is more frequent among males ${ }^{6}$.

NF1 has an approximate incidence of 1 out of every 3000 births ${ }^{7-9}$, being one of the most common neurogenetic disorders $^{8}$.

Molecular pathogenesis of the disease may be explained by the absence of the synthesis of a protein called neurofibromine ${ }^{2,8,10}$, which is composed of 2818 aminoacids

${ }^{8}$. Molecular analysis of neurofibromine has revealed similarity between part of it and the catalyst domain of a protein which acts as negative regulator of Ras guanosine triphosphate GTPase ${ }^{8}$. In many cells, Ras GTP helps oncogenetic transformation both in vivo and in vitro ${ }^{8}$. The loss of NF1 genetic expression leads to the absence of neurofibromine and to increased Ras GTP activity with consequent increase in cellular proliferation and formation of tumors $^{8}$. A chromosome 17 mutation is responsible for NF $1^{2,10}$. The disease may be clinically characterized by ${ }^{5}$ café au lait spots, skin, neural or vascular neurofibromas, intracranial and medullary tumors, skeletal changes, lung stenosis, low stature, endocrine abnormalities and learning difficulties. Some associated diseases should also be mentioned, such as pheocrhomocytoma ${ }^{9,11,12}$, thyroid carcinoma ${ }^{7,11}$, polycystic kidney ${ }^{7}$, aorta aneurysm ${ }^{7}$ and renal artery stenosis $^{9,13}$

Diagnosis is confirmed by the presence of at least six café au lait spots larger than $1.5 \mathrm{~cm}$ in diameter. Skin or subcutaneous neurofibromas in childhood also confirm the diagnosis ${ }^{13}$. The presence of pharyngeal ${ }^{12}$, laryngeal ${ }^{12}$ and mediastinum ${ }^{5}$ neurofibromas, and macroglossia ${ }^{10}$ may lead to airway obstruction, which is clinically manifested by dyspnea, dysphagia or dysphonia ${ }^{12}$.

Skeletal changes are seen in $50 \%$ of cases and include 11 scoliosis, mandibular deformity, congenital pseudo-arthrosis and cervical abnormalities.

Scoliosis is present in $2 \%$ of patients ${ }^{9}$, impairing respiratory mechanics, gaseous changes and pulmonary circulation ${ }^{14}$. Abnormal ribcage development directly affects the elastic properties of respiratory system ${ }^{14}$. There is change in pulmo- nary ventilation and perfusion ratio with the development of generalized hypoventilation ${ }^{14}$. Pulmonary artery hypertension, respiratory failure and cor pulmonale may appear with age ${ }^{14}$.

Cervical involvement is due to tumor infiltration or to abnormalities in spinal ligaments with possibility of atlanto-occipital luxation ${ }^{15}$.

The presence of giant plexiform neurofibroma in the head may lead to eyelid ptosis, facial gigantism and visual problems ${ }^{15}$. Macroglossia may also be present ${ }^{10}$. Facial deformities require surgical treatment ${ }^{15}$.

Pheochromocytoma is present in approximately $1 \%{ }^{9,12,13}$ of patients and is the major cause for systemic hypertension $(\mathrm{SH})$ in adults ${ }^{6}$. Its manifestation in children is uncommon ${ }^{5,9}$ and in this group of patients, $\mathrm{SH}$ is more commonly manifested by renal artery stenosis ${ }^{13}$.

Some preoperative tests are recommended to prevent complications and help choosing the best anesthetic technique in a case-by-case basis.

CT scan, MRI and indirect laryngoscopy are indicated to evaluate airways involvement ${ }^{12}$. Preoperative tracheostomy should be considered to assure safe general anesthesia.

In patients with scoliosis and lung disease, chest X-Rays, blood gases analysis and spirometry are indicated ${ }^{12}$.

For all patients, urinary catecholamine levels should be determined due to their association with pheochromocytoma ${ }^{12}$. Normal values for 24-hour urine are below $0.1 \mathrm{mg}$ free epinephrine and norepinephrine, $1.3 \mathrm{mg}$ total metanephrine 10 $\mathrm{mg}$ vanillylmandelic acid and $15 \mathrm{mg}$ homovanillic acid. Comma, dehydration or excessive stress increase the secretion of such components ${ }^{16}$.

Hypophysis function evaluation is recommended in patients with low stature or referring sexual dysfunction.

General anesthesia may be successful in Von Recklinghausen patients when the possibility of airway obstruction is thoroughly investigated and when sensitivity to neuromuscular blockers is valued.

Difficult intubation may be caused by airways obstruction by the presence of neurofibroma, especially in the larynx and pharynx. Patients with history of complication-free intubation are not free from risks since the disease is progressive ${ }^{7}$. There is a report on impossibility of ventilation under mask with tracheostomy after anesthetic induction ${ }^{10}$.

NF1 patients have increased sensitivity to nondepolarizing neuromuscular blockers ${ }^{4,5,8-10,12,13}$. Adefect on pre-synaptic receptor and/or a change in post-synaptic receptor response may explain this abnormal response ${ }^{4}$. Neuromuscular function monitoring is recommended when general anesthesia is planned with this class of drugs ${ }^{9,10,12}$.

Literature is controversial with regard to succinylcholine. Some authors refer decreased sensitivity ${ }^{4}$, others normal ${ }^{6,11}$ and still others increased sensitivity $5,7,9,10,13$.

It has been reported that neuraxial block may be successfully performed ${ }^{4,5,7,12,13,17}$. In our case, due to the urgency of the situation, it was impossible to perform more complete preoperative tests and spinal anesthesia was chosen to spare patient from tracheal intubation risks. There might be technical Vol. 55, N 6, Novembro - Dezembro, 2005 
difficulties due to marked spinal shift ${ }^{13}$ or to the presence of asymptomatic neurofibroma in the needle pathway ${ }^{7,13}$, which were not present in our patient.

Spinal anesthesia was possible in this case with no need for airway handling.

\section{REFERÊNCIAS - REFERENCES}

01. Richardson MG, Setty GK, Rawoof SA - Responses to nondepolarizing blockers and succinylcholine in von Recklinghausen neurofibromatosis. Anesth Analg, 1996;82: 382-385.

02. Sazar MS, Israel MA - Tumores Primários e Metastáticos do Sistema Nervoso, em: Braunwald E, Fauci AS, Kasper DL et al Medicina Interna. Rio de Janeiro, Mc Graw-Hill Interamericana do Brasil, 2002;2594-2603.

03. Krishna G - Case history number 85 . Neurofibromatosis, renal hipertensión, and cardiac dysrhythmias. Anesth Analg, 1975;54:542-545.

04. Dounas M, Mercier FJ, Lhuissier C et al - Epidural analgesia for labour in a parturient with neurofibromatosis. Can J Anaesth, 1995;42:420-424.

05. Stoelting SF, Dierdorf SF - Diseases of the Nervous System, em: Stoelting SF, Dierdorf SF - Anestesia and Co-Existing Disease. $4^{\text {th }}$ Ed, New Cork, Churchil Livingstone, 2002;233-298.

06. Naguib M, Al-Rajeh SM, Abdulatif M et al - The response of a patient with von Recklinghausen's disease to succinylcholine and atracurium. Middle East J Anesthesiol, 1988;9:429-434.

07. Rodríguez YC, Garcia MZ, Madrid MT et al - Anestesia en la enfermedad de von Recklinghausen. A propósito de un caso. Rev Esp Anest y Reanim, 1991;38:94.

08. Arun D, Gutmann DH - Recent advances in neurofibromatosis type 1. Curr Opin Neurol, 2004;17:101-105.

09. Delgado JM, de la Matta Martin MM - Anaesthetic implications of von Recklinghausen's neurofibromatosis. Paediatr Anaesth, 2002;12:374-379.

10. Baun VC, O'Flaherty JE - Anestesia for Syndromes of Childhood, em: Baun VC, O'Flaherty JE - Anestesia for Genetic, Metabolic, and Dysmorphic Syndromes of Childhood. Philadelphia, Lippincott Williams \& Wilkins, 1999;218-219.

11. Martz DG Jr, Schreibman DL, Matjasko MJ - Neurologic Diseases, em: Benumof JL - Anesthesia \& Uncommon Diseases. $4^{\text {th }}$ Ed, Philadelphia, WB Saunders, 1998;3-37.
12. Partridge BL - Skin and Bone Disorders, em: Benumof JL - Anesthesia \& Uncommon Diseases. $4^{\text {th }}$ Ed, Philadelphia, WB Saunders, 1998;423-458.

13. Smith MF - Skin and Connective Tissue Diseases, em: Katz J, Steward DJ - Anesthesia and Uncommon Pediatric Diseases. Philadelphia, WB Sanuders, 1987;378-428.

14. Conception M - Anestesia para Cirurgia Ortopédica, em: Rogers MC, Tinker JH, Covino BG et al - Princípios e Prática de Anestesiologia. Rio de Janeiro, Guanabara Koogan, 1996; 1618-1638.

15. Mcleod ME, Creighton RE - Central Nervous System Disease, em: Katz J, Steward DJ - Anesthesia and Uncommon Pediatric Diseases. Philadelphia, WB Saunders, 1987;49-64.

16. Spergel G - Feocromocitoma, em: Bondy PK, Junior PVD, Douglas RG et al - Manual Merck de Medicina. $16^{\mathrm{a}} \mathrm{Ed}$, São Paulo, Roca, 1992;1085-1088.

17. Fisher MM - Anaesthetic difficulties in neurofibromatosis. Anaesthesia, 1975;30:648-650.

\section{RESUMEN}

Barbosa FT, Figueiredo AV, Cunha RM, Albuquerque MAC - Raquianestesia para Cirugía Ortopédica de Urgencia en una Paciente Portadora de Enfermedad de Von Recklinghausen. Relato de Caso

JUSTIFICATIVA Y OBJETIVOS: La enfermedad de Von Recklinghausen es una enfermedad neurogenética causada por una anomalía en el cromosoma 17. Este relato tiene por objetivo describir la conducta anestésica en una paciente con enfermedad de Von Recklinghausen sometida a cirugía ortopédica de urgencia.

RELATO DEL CASO: Paciente del sexo femenino, 28 años, portadora de la enfermedad de Von Recklinghausen, sometida a cirugía ortopédica en un hospital de emergencia con raquianestesia. No presentó complicaciones en el período intra-operatorio, tampoco en la sala de recuperación pos-anestésica. Tuvo alta hospitalar en el $4^{\circ}$ día de pos-operatorio.

CONCLUSIONES: En el caso relatado fue posible la realización de la raquianestesia sin haber necesidad de manejar de la vía aérea. 